Itinerario, Vol. 46, No. 1, 172-183. (C) The Author(s), 2022. Published by Cambridge University Press on behalf of Research Institute for History, Leiden University. This is an Open Access article, distributed under the terms of the Creative Commons Attribution-NonCommercial-ShareAlike licence (https://creativecommons.org/licenses/by$\mathrm{nc}-\mathrm{sa} / 4.0 /$ ), which permits non-commercial re-use, distribution, and reproduction in any medium, provided the same Creative Commons licence is included and the original work is properly cited. The written permission of

\title{
Histories of Empire and Environmental Legacies in Africa
}

\author{
IVA PE $\breve{S} A^{*}$ \\ E-mail: i.pesa@rug.nl
}

Jacob S. T. Dlamini. Safari Nation: A Social History of the Kruger National Park. Athens: Ohio University Press, 2020.

Nicholas Westcott. Imperialism and Development: The East African Groundnut Scheme and Its Legacy. Oxford: James Currey/Boydell \& Brewer, 2020.

Emily Brownell. Gone to Ground: A History of Environment and Infrastructure in Dar es Salaam. Pittsburgh: University of Pittsburgh Press, 2020.

Societal debates about climate change have rekindled interest in environmental history approaches. This review article considers three recent books in African environmental history, on the Kruger National Park, the East African Groundnut Scheme, and on infrastructure in postcolonial Dar es Salaam. Why is it important to study the empireenvironment nexus? How do African experiences relate to discussions on the Anthropocene? Taking environmental dynamics into account enriches understandings of social, political, and cultural relationships and sheds light on imperialism and its complex legacies. This article makes the case for the importance of environmental history as a category of analysis, encouraging other scholars to think "with" the environment in broader debates concerning power, identity, and social change.

Keywords: environmental history, Africa, national parks, agricultural schemes, urbanism

The importance of environmental history to studies of imperialism was made abundantly clear by the early works of Alfred Crosby. In his 1972 book, The Columbian Exchange, and subsequently in Ecological Imperialism, Crosby argued that the most profound changes caused by imperialism were not social or political, but environmental and 
biological. ${ }^{1}$ The exchange of diseases, crops, animals, and environmental management practices across oceans and continents transformed local ecologies and concomitantly socioeconomic and political organisation. These changes could be destructive as well as generative: while new diseases in some cases decimated populations, new crops such as maize could also enable higher yields, resilience to environmental fluctuations, and facilitate political centralisation, as James McCann showed for Africa. ${ }^{2}$ Despite widespread praise for Crosby's work, it took several decades for these ideas to become mainstream. $^{3}$

Imperialism undeniably spurred environmental transformation. In twentieth-century Africa, the focus of this review essay, imperialism and colonialism altered ecosystems and reordered environmental relationships: through new crops and farming practices, forestry, animal husbandry, and resource extraction, as well as through "conservation" efforts, knowledge regimes, and management interventions. ${ }^{4}$ As Corey Ross has noted, it is remarkable that "ecology rarely occupies centre stage in histories of empire." Africanists have certainly produced excellent environmental histories. Noteworthy is William Beinart's work, which has ranged from wildlife conservation and agriculture to the role of knowledge and expertise in shaping environmental change in southern Africa. ${ }^{6}$ Likewise, Jane Carruthers has studied national parks in South Africa from the perspectives of environmental, social, and political history, showing that these approaches are intertwined and complementary. ${ }^{7}$ Yet the focus of environmental history research in Africa has been uneven: while topics such as wildlife conservation and anti-soil-erosion measures have attracted a fair share of attention, environmental transformations in urban areas or in the context of industry have not been fully explored. ${ }^{8}$ Moreover, histories of empire which focus on issues such as governance, war, or identity politics rarely consider environmental issues as worthy of detailed examination. ${ }^{9}$

Recently, however, this has started to change. Topical debates about climate change and the Anthropocene, the proposed geological era in which human activity has become the dominant influence on climate and the environment, have placed humanenvironment relations at the forefront of contemporary academic research. ${ }^{10}$ Yet although the Anthropocene is a planetary phenomenon, its effects are lived variously in different parts of the world. ${ }^{11}$ Anthropocene discussions have so far barely started to account for unequal histories of imperialism, global capitalist accumulation by dispossession, or historically rooted patterns of environmental inequality. ${ }^{12}$ In this respect, Africanist environmental historians have important contributions to make to Anthropocene discussions. As the three works reviewed here show, environmental histories of particular African experiences can illustrate how imperial legacies of agricultural management or conservation continue to shape socio-natural relationships in the present. Through a study of Dar es Salaam in the 1970s and 1980s, Emily Brownell demonstrates how histories of "making do"- by using charcoal instead of paraffin or burnt bricks instead of concrete-illustrate how people have dealt with crisis, shortage, and environmental transformation in the past. ${ }^{13}$ Such historical examples can prove vitally important in dealing with future climate crisis and environmental uncertainty. Deeper and more complex histories of environmental change in Africa are therefore urgently needed. 
Through a review of three books, this essay explores why it is important to study the empire-environment nexus. Although the authors of these works might not self-identify as environmental historians, all three books speak about complex human-environment relations and their (un)intended consequences in twentieth-century Africa.

\section{National Parks and Conservation: Pluralising Histories}

Wildlife conservation has long been a prominent topic in African environmental history. Recent historiography has forcefully challenged the view of conservation as a simple effort to preserve pristine nature. John MacKenzie demonstrated how, across Africa, nature conservation was often an attempt to control population. While at the start of the twentieth century African hunters' access to game was increasingly curtailed, European hunters and colonial administrators demarcated game reserves and national parks as their exclusive preserve. ${ }^{14}$ Beinart's work has traced how conservationist ideas emerged in South Africa. He shows that imperial anxieties about African livestock herding and agricultural production informed narratives about environmental degradation, which legitimised the formation of protected areas and national parks. ${ }^{15}$ Exclusion and privilege continue to shape contemporary conservation practices. In countries such as Zimbabwe where whites are minorities, some have invested in land and animals as a mechanism of "social escape" from the realities of black majority governance. ${ }^{16}$ Quite differently, the focus on animals and nonhuman actors in national parks is an exciting development in this field. Nuanced accounts of how imperial conservation measures sought to control animals, plants, and microbes - but never managed to do so - enrich our understanding of what national parks are and do. ${ }^{17}$

Jacob Dlamini's book Safari Nation approaches these discussions about nature conservation and national parks from a highly innovative perspective. The Kruger National Park (KNP) is one of the continent's most emblematic sites of conservation, an icon of South African identity, which has been studied extensively. ${ }^{18}$ Yet these accounts have never placed Africans, Coloureds, and Indians (a group Dlamini calls "blacks") at the centre of analysis. White histories of the KNP, Dlamini argues, portrayed blacks chiefly as labourers or poachers, but this image is far from complete. Through "histories of presence" which foreground hunters, domestic servants, wood gatherers, and African tourists to the KNP, Dlamini seeks "a much more cosmopolitan, democratic, and ultimately more hopeful history of approaches to the KNP, to conservation, and to the land question" (260).

The book gives a detailed history of how the colonial order persistently criminalised African actions, such as hunting or burning charcoal, making Africans, wild animals, and the environment appear as "natural enemies" (38). Dlamini shows that there is nothing "natural" about such depictions of blacks as "nature's denizens," which persisted throughout the bulk of the twentieth century. Instead, the book focuses on "the politicization of nature and the naturalization of politics" (9). Dlamini traces how the park's history made black labour invisible, whether that of park guards, women clearing grass, or labour migrants travelling through the park. A good example is that of "squatters": 
despite denunciation by officials, the presence of "squatters" in the park was valuable, as this group provided flexible labour. But their ability to stay in the park fundamentally altered "their relationship with their land," not least because they became obliged to pay taxes and rent (79). In an attempt to reveal this "hidden history of the KNP," the book asks: "What did the park mean for the thousands of blacks who visited throughout the latter half of the twentieth century? What did they see and how did they see it?" (184).

Dlamini asserts that the park naturalised Africans in a political move intended "to strip them of political agency and [. . .] deny their claims of political equality" (10). Due to "subversive African agency" this never quite succeeded, though (73). Dlamini shows, for example, that the histories of wildlife protection and the mining industry were thoroughly intertwined. By limiting African access to land and by denying hunters an independent livelihood, "many African men had limited choices but to turn to the mining industry and white-controlled agriculture for wages" (72). Rather than sketching a view of this labour migration as part of a process of underdevelopment and capitalist exploitation, Dlamini chooses to focus on flows, movement, and African agency. He highlights that the park became a transit point of the Witwatersrand Native Labour Association, part of "a historical network of flows and paths stretching over great distances" (65). As Patrick Harries has also shown in his pathbreaking study, mineworkers travelling through the park to Mozambique regularly hunted game "illicitly" to earn additional income. ${ }^{19}$ Paying attention to such vignettes, which are notoriously hard to trace in the archives, recasts debates on labour migration, African agency, and the role of the KNP as a deeply political place.

Another interesting angle from which to approach the KNP is tourism. On the one hand, certain Africans were cast as naturalised objects, "part of the tourist experience" (80). International visitors came to desire "the authentic experience of Africans in their "true conditions" (125). That this image was atavistic and required the population groups living around the KNP to enact a stylised lifestyle did not seem to matter. For instance, the "traditional Zulu dances" continue to be popular in the KNP today. ${ }^{20}$ On the other hand, Dlamini pays attention to the growing group of the black elite for whom, particularly after 1950, mobility and tourism to the KNP became a way of "enacting modern ways of engaging with the land and its landscape" (92). Through leisurely travel and trains, certain blacks were for the first time allowed to discover their own country. Mobility was a key way of fashioning new identities and worlds. At the same time, Dlamini juxtaposes this increased freedom to the stark fact that until the 1970s more Africans visited the park as domestic servants than as regular tourists. Paying attention to who can visit the park and how reveals much about the politics, meaning, and symbolism of the KNP.

Such an analysis conveys the multiple meanings of "nature" and the KNP: beyond the physical environment, nature involved "ideas about access, entitlement, and value." Nature was thus an inherently political and ideological concept, which could serve "to explore different possibilities of what South Africa was or could become" (7). Whereas the KNP had long sought to present itself "as pristine wilderness [. . .] removed from the soiled political economy of southern Africa" (12), this image definitely started 
to crumble in the 1990s. The park could no longer afford to be seen as a "white man's playground" and blacks were now looking to the KNP to make claims to the South African state, as rights-bearing subjects (251). Dlamini depicts how, "Bantustan leaders used conservation to issue veiled challenges against apartheid" (193). Yet due to the park's long racist and repressive history, "the KNP remained an 'ambiguous symbol' for many of its neighbors" (217). While after 1994 attempts were made to democratise park management and integrate local communities in the management of conservation areas, these attempts did not always go smoothly. Although Nelson Mandela powerfully used nature to assert a common South Africanness, Dlamini comes to a much more sobering conclusion about the ability of the park to act as a national symbol.

The key contribution of Dlamini's book is to convincingly show that "the KNP was part of a wider social and political ecosystem in which humans - especially the African communities living adjacent to the park-were a key part" (224). Yet in making this claim, Dlamini regularly takes his readers to localities far removed from the park: along the railway line to Durban or following mineworkers from Johannesburg to Mozambique. While this strengthens Dlamini's focus on "routes" and "roots," I sometimes desired a firmer grounding in place. Likewise, as Dlamini explores the KNP's political meaning and symbolism, he could have delved deeper into its actual materiality: how does the environment enable or deter hunting, how is travelling hampered by tree cover, and which opportunities does the KNP afford for agricultural settlement or livelihoods? While Dlamini masterfully shows that the environment can be political, a deeper exploration of which environmental factors enable which kinds of politics would have made this an even stronger book.

\section{Megaprojects, Nature, and Human Hubris}

Africanist historians have paid ample attention to what James Scott has termed "megaprojects," showing that large dam schemes and agricultural projects rarely managed to transform nature according to predefined ideals of legibility, rationality, and order. ${ }^{21}$ Such works have nuanced discussions about "success" and "failure," as well as what "development" means. Nicholas Westcott's Imperialism and Development sets out to write the history of the East African groundnut scheme, one of the continent's largest agricultural projects and a dramatic example of "failure." Surprisingly, its history has never been studied in depth before. ${ }^{22}$

The main question this book attempts to answer is: "why do governments time and again pursue large-scale projects that lead ineluctably to either predictable disaster or ever-escalating expense, or both, despite all the warnings of experts and locals?" (21). The groundnut scheme in present-day Tanzania was operational from November 1946 until January 1951. A total of $£ 36.5$ million was invested in the scheme, which had the aim of generating the largest continuous area of mechanised arable land in the world, employing nearly 27,000 Africans at its peak. This scheme became a prime lesson in How Not to Do It: production targets were never met, costs turned out many times higher than budgeted for, tractors got stuck before reaching the fields, and droughts 
ruined yields. Although Westcott describes the groundnut scheme as "the most ambitious development project ever undertaken by the British Government," it was, at the same time, "a development and financial disaster and a political scandal" (1).

At the end of the Second World War, Britain faced an acute food shortage, particularly in fats and oils. In addition, war debt caused a foreign exchange crisis-prompting British politicians to revalue imperial possessions as production areas capable of generating export revenues. This situation "made Africa more important to the imperial economy than it had ever been before" (17). Through ambitious air surveys, Tanzania was identified as a promising area to grow groundnuts for export. Based on faulty assumptions about yields, soil, weather, and disease, a blueprint was drawn up to plant three million acres with groundnuts. Huge efforts were expended to build a railway, dig a port, and clear land using tractors to enable groundnut exports. Westcott shows convincingly that the scheme was always driven more by metropolitan politics than by any effort to consider Tanzanian needs. Nonetheless, the scheme dovetailed with colonial "development" projects, particularly those of the so-called second colonial occupation after 1945, when imperial funding for and direct involvement in agricultural schemes greatly increased. Attempts to raise African agricultural productivity and ameliorate the living conditions of colonial subjects were built on firm beliefs in the potential of rapid transformation and "an absolute faith in the ability of science to triumph over nature" (15). ${ }^{23}$ This was coupled with a focus on "scientific agriculture," "mechanisation and modern soil conservation and fertilisation methods" (54). Even when agronomists raised objections, political imperatives shrugged these off.

Ironically, more groundnuts were imported as seed to Tanzania than ever left the country as exports. By now this is a familiar story: large-scale mechanised and state-driven agriculture is less effective and more vulnerable to the vagaries of weather and soil conditions than small-scale locally adapted practices. ${ }^{24}$ Westcott describes how local agricultural practices were "appropriate to an environment with poor soils and erratic rainfall," yet none of the British "experts" cared to listen (90). Westcott's book is primarily written from a British perspective, but what he does note about Tanzanian initiative-building primarily on the works of Matteo Rizzo ${ }^{25}$-is revealing: surrounding population groups benefitted from the sudden investments in the groundnut scheme by selling vegetables, meat, and trade goods to British "groundnutters" and Tanzanian labourers; the National Development Corporation of Tanzania took over the lands cleared by the groundnut scheme after its demise and turned them into tobacco farming, cattle ranching, and experimental mixed farming schemes; cashew trees, planted by local farmers, were grown successfully and fed into a profitable export trade to India. By 1961 Tanzania exported 40,000 tons of cashew nuts annually. Finally, Julius Nyerere used the lands cleared by the groundnut scheme as a training ground for liberation movements, thus contributing to "a rather different transformation of Africa to that envisaged by its originators" (182).

Apart from the blunders in political planning, mistakes made in execution, and faulty calculations of yields and costs, environmental factors played a major role in the "failure" of the groundnut scheme. Westcott uses mainly figurative language to describe the 
struggles of "bulldozers versus the bush" (24). The groundnut scheme aspired "to "tame nature' and impose control over its unruly reality through 'scientific' or mechanised farming," ambitions which failed miserably (22). British employees of the groundnut scheme complained about "MMBA - miles and miles of bloody Africa" and Westcott describes how "the African bush put up a stiff fight against the new invaders" (99, 101). The scheme's planners belatedly realised that "nature could not be 'bustled a bit" (206). A more dynamic depiction of environmental factors would have befitted this otherwise meticulously researched book. Stefan Esselborn, who focuses on the environmental reasons behind the groundnut scheme's failure, explains that a conviction existed "that the sorely needed agricultural modernization of Tanzania could be brought about only by radical, large-scale, and highly centralized measures." The scheme was devised against "the 'primitive ways of the African peasant,' which were thought to be inefficient, wasteful, and even actively harmful to the soil." ${ }^{26}$ Accounting for how such beliefs about African agriculture came into being and what kinds of effects this had on Tanzanian environments - which mechanised farming would profoundly transform-would have made this book even richer.

Despite the blatant failure of the groundnut scheme, Westcott shows that "the dreams of modernising African agriculture and transforming the wilderness into a productive asset live on" (210). Nyerere's ujamaa schemes displayed much of the "high modernism" which Scott depicted. ${ }^{27}$ Westcott concludes with a plea to study failure more seriously, as "the postindependence enthusiasm for state-led development has left the African landscape littered with the industrial skeletons of failed parastatals and state-run enterprises" (212).

\section{Urbanism, Infrastructure, and Informality}

Brownell's book takes up this challenge of studying "failure," but from a wholly different perspective. She studies infrastructural breakdown in Dar es Salaam in the 1970s and 1980s and the effects this had on the urban environment. Through stories of waiting for the bus, stoppages at cement factories, or the absence of food in urban stores, Brownell argues that in "navigating around disrepair, urban communities reshaped their built environment in profound ways" and envisaged "a new, grounded path to development" (6). She reveals how Dar es Salaam's "environment has reflected a persistent tension and collaboration between the 'city' and the 'village"' (3). Brownell's book illustrates that the city could not exist without rural resources, ranging from material for making bricks to charcoal and food. By paying attention to these "everyday acts of provisioning for urban lives," Brownell shows "how urban communities became not more cut off from 'nature' but rather more entrenched in it" (5). Through such an invitation to rethink "what materials and infrastructures constitute a 'modern' city," this book fundamentally reshapes the debate about what "urbanism" is (7). ${ }^{28}$

In a brilliant chapter on mud bricks and concrete, Brownell shows how building materials were continuously reconceptualised. While initially concrete was hailed as a modern building material for formal neighbourhoods, once it became scarce in the 1970s, mud bricks were re-signified "as part of an alternative Third World modernity," 
whereas concrete was rejected as "imperial" (13). Building materials were, thus, "imbued with politics [and] morality" (64). Brownell asserts that "finding belonging in the city" was premised on "securing the very materials of provisioning for life in the city" (37). Whereas cement was highly dependent on foreign expertise and imported oil, brickmaking was locally independent and "fit into an ideal type of self-help building promoted" by Nyerere's socialist state (83). Brownell shows that "concrete, mud, sand, thatch, and brick existed in concert with each other — side by side - replacing, overlapping, and repairing" (87). For example, by renting out rooms, house owners could engage in incremental building and plan to buy concrete. Brownell shows how this incremental building became "a way to secure space in the city" and thereby "incompletion becomes a permanent state" (89). In this sense, "the materiality of Dar's houses reveals both state and family aspirational narratives about the future" (13).

Brownell rejects the distinction between "planned" and "unplanned" or "formal" and "informal" neighbourhoods, showing their profound interdependency. She argues that population movements and exchanges between the formal city centre and informal periurban areas in fact constituted "the heart of African urbanism" (42). With affection, Brownell describes how "unplanned neighborhoods emerged along the creeks, valleys, hills, and mangroves of Dar's transforming borderland," as "families realized that there were many practical reasons to avoid planned areas where there was less room for improvising space to meet the new needs of urban life through gardening or keeping livestock" (47). In an ongoing process, which intensified as a result of economic malaise following the global oil crises, Dar es Salaam's urbanites moved to peri-urban areas to buy land and start farms - sometimes formally ordered by ujamaa legislation, sometimes voluntarily. Brownell masterfully shows these "different ways of inhabiting the city" (60).

Another original chapter is that on charcoal, which Brownell describes as "an alternative, autarkic fuel source" (14). Charcoal symbolised the city's interdependence with its hinterland, but the resource was also "entangled in global anxieties about energy, environmental crisis and reappraising the terms of international development" (149). While charcoal was a "quintessentially urban fuel," it "meant many different things to many different people": it promised resource sovereignty to the Tanzanian state; it offered producers a lucrative way to participate in the urban economy; and due to its lack of regulation, it was also an anarchic fuel source (151). Yet although charcoal had the potential of being exported, it also caused massive deforestation: "while the expanding city gave rise to a larger charcoal market, land cleared for new homes, businesses, and ujamaa villages literally fueled the trade" (158). Brownell shows that charcoal was not an atavistic local fuel source, instead it was "tied up with the rising price of oil and other 'modern fuels' as well as the failed promises of modernization and the absence of alternative [urban] fuel infrastructures" (162). Charcoal, ultimately, "was a way to survive the rupturing economy" (180). This nicely ties into recent work which has reappraised the continued popularity of charcoal, despite international attention for "deforestation" and "climate change."29

Brownell convincingly argues that "writing more expansive environmental histories of [urban areas in] the Global South is vitally important" (8). Africanist historians have so far largely failed to follow her advice to "give voice to the frequently banal 
environmental forces of water, mud, [and] sand" (11). "African cities [. . .] offer to urban environmental history a particular imperative to highlight process and to continue to think of unfolding environments and landscapes. [. . .] This slow accretion of resources was utterly future-oriented, modular, and repairable, and used what was locally available" (90). Brownell calls attention not just to otherwise overlooked informal activities of food provisioning and waste handling, but also to repair, tinkering, and innovation in urban settings. ${ }^{30}$ The book invites us to "bring these negotiations over materials and environments back into the story of the ongoing struggle for decolonization," which ultimately shows that "urban Africans have a deep capacity to solve problems and reimagine the present" (186). ${ }^{31}$

\section{Concluding Remarks}

These three works show that there is sufficient scope to expand studies of environmental history in Africa. The public debate about climate change, sustainability, and the Anthropocene also gives this research urgency. I suggest there are three immediately feasible ways forward. First, histories of nature conservation in Africa should abandon their narrow focus on national parks to pay attention to how parks are embedded in broader ecosystems and thick relationships with surrounding population groups. Dlamini's book shows some fruitful ways of doing this. Secondly, histories of "development schemes" in Africa cannot be complete without taking environmental dimensions seriously. Going beyond debates about planning, technology, and execution, it is imperative to consider how development schemes set out to transform landscapes and labouring bodies. Thirdly, urban environmental histories should figure much more prominently in Africanist historiography. Africa has already become an urban continent, so histories of charcoal, building materials, and urban waste are vital. Enriching African environmental histories in these ways ultimately sheds light on issues of imperial legacies, power, and ideology, all crucial considerations in any good work of history.

\section{Bibliography}

Beinart, William. The Rise of Conservation in South Africa: Settlers, Livestock, and the Environment 1770-1950. Oxford: Oxford University Press, 2003.

Beinart, William, and JoAnn McGregor, eds. Social History and African Environments. Oxford: James Currey, 2003.

Beusekom, Monica van. Negotiating Development: African Farmers and Colonial Experts at the Office du Niger, 1920-1960. Portsmouth: Heinemann, 2002.

Bonneuil, Christophe, and Jean-Baptiste Fressoz. The Shock of the Anthropocene: The Earth, History and Us. London: Verso Books, 2016.

Branch, Adam, and Giuliano Martiniello. "Charcoal Power: The Political Violence of Non-Fossil Fuel in Uganda." Geoforum 97 (2018): 242-52.

Brownell, Emily. Gone to Ground: A History of Environment and Infrastructure in Dar es Salaam. Pittsburgh: University of Pittsburgh Press, 2020. 
Carruthers, Jane. The Kruger National Park: A Social and Political History. Pietermaritzburg: University of Natal Press, 1995.

- National Park Science: A Century of Research in South Africa. Cambridge: Cambridge University Press, 2017.

Crosby, Alfred W. Jr. The Columbian Exchange: Biological and Cultural Consequences of 1492. Westport: Greenwood Publishing, 1972.

Crosby, Alfred W. Jr. Ecological Imperialism: The Biological Expansion of Europe, 900-1900. Cambridge: Cambridge University Press, 1986.

D'Avignon, Robyn. "Primitive Techniques: From 'Customary' to 'Artisanal' Mining in French West Africa." Journal of African History 59:2 (2018): 179-97.

Dlamini, Jacob S. T. Safari Nation: A Social History of the Kruger National Park. Athens: Ohio University Press, 2020.

Esselborn, Stefan. "Environment, Memory, and the Groundnut Scheme: Britain's Largest Colonial Agricultural Development Project and Its Global Legacy." Global Environment 11 (2013): 58-93.

Firenzi, Tara. "The Changing Functions of Traditional Dance in Zulu Societies: 1830-Present." International Journal of African Historical Studies 45:3 (2012): 403-25.

Gewald, Jan-Bart, Marja Spierenburg, and Harry Wels, eds. Nature Conservation in Southern Africa: Towards Sentient Conservation? Leiden: Brill, 2018.

Harries, Patrick. Work, Culture, and Identity: Migrant Laborers in Mozambique and South Africa, c. 1860-1910. Portsmouth: Heinemann, 1994.

Hecht, Gabrielle. Being Nuclear: Africans and the Global Uranium Trade. Cambridge: MIT Press, 2012. Hecht, Gabrielle. "Interscalar Vehicles for an African Anthropocene: On Waste, Temporality, and Violence." Cultural Anthropology 33:1 (2018): 109-41.

Hodge, Joseph Morgan. Triumph of the Expert: Agrarian Doctrines of Development and the Legacies of British Colonialism. Athens: Ohio University Press, 2007.

Hogendorn, J. S., and K. M. Scott. "The East African Groundnut Scheme: Lessons of a Large-Scale Agricultural Failure.” African Economic History 10 (1981): 81-115.

Hughes, David McDermott. Whiteness in Zimbabwe: Race, Landscape, and the Problem of Belonging. New York: Palgrave Macmillan, 2010.

Isaacman, Allen F., and Barbara S. Isaacman. Dams, Displacement, and the Delusion of Development: Cahora Bassa and Its Legacies in Mozambique, 1965-2007. Athens: Ohio University Press, 2013.

Kreike, Emmanuel. Scorched Earth: Environmental Warfare as a Crime Against Humanity and Nature. Princeton: Princeton University Press, 2021.

MacKenzie, John M. The Empire of Nature: Hunting, Conservation and British Imperialism. Manchester: Manchester University Press, 1988.

McCann, James C. Maize and Grace: Africa's Encounter with a New World Crop, 1950-2000. Cambridge: Harvard University Press, 2005.

McNeill, John R. Something New Under the Sun: An Environmental History of the Twentieth-Century World. New York: W. W. Norton, 2000.

Mwatwara, Wesley. "A History of State Veterinary Services and African Livestock Regimes in Colonial Zimbabwe, c. 1896-1980.” PhD diss., Stellenbosch University, 2014.

Peša, Iva. "Crops and Copper: Agriculture and Urbanism on the Central African Copperbelt, 19502000." Journal of Southern African Studies 46:3 (2020): 527-45.

_. "Mining, Waste and Environmental Thought on the Central African Copperbelt, 1950-2000." Environment and History (2020), https://doi.org/10.3197/096734019X15755402985703.

_. "Sawdust Pellets, Micro Gasifying Cook Stoves and Charcoal in Urban Zambia: Understanding the Value Chain Dynamics of Improved Cook Stove Initiatives." Sustainable Energy Technologies and Assessments 22 (2017): 171-6. 
Pilossof, Rory. The Unbearable Whiteness of Being: Farmers' Voices from Zimbabwe. Harare: Weaver Press, 2012.

Rizzo, Matteo. "What Was Left of the Groundnut Scheme? Development Disaster and Labour Market in Southern Tanganyika, 1946-1952." Journal of Agrarian Change 6:2 (2006): 205-38. Ross, Corey. Ecology and Power in the Age of Empire: Europe and the Transformation of the Tropical World. Oxford: Oxford University Press, 2017.

Scott, James C. Seeing like a State: How Certain Schemes to Improve the Human Condition Have Failed. New Haven: Yale University Press, 1999.

Showers, Kate B. Imperial Gullies: Soil Erosion and Conservation in Lesotho. Athens: Ohio University Press, 2005.

Swart, Sandra. "Writing Animals into African History." Critical African Studies 8:2 (2016): 95-108.

Tischler, Julia. Light and Power for a Multiracial Nation: The Kariba Dam Scheme in the Central African Federation. New York: Palgrave Macmillan, 2013.

Twagira, Laura Ann. "Introduction: Africanizing the History of Technology." Technology and Culture 61:2 (2020): S1-19.

Westcott, Nicholas. Imperialism and Development: The East African Groundnut Scheme and Its Legacy. Woodbridge: James Currey, 2020.

Wood, Alan. The Groundnut Affair. London: The Bodley Head, 1950.

Yusoff, Kathryn. A Billion Black Anthropocenes or None. Minneapolis: University of Minnesota Press, 2018.

\section{Notes}

* Iva Pesa is an Assistant Professor in Contemporary History at the University of Groningen. Building on long-term fieldwork, her research focuses on the social and environmental history of resource extraction in various African localities.

1 Crosby, The Columbian Exchange; Crosby, Ecological Imperialism.

2 McCann, Maize and Grace.

3 See McNeill, Something New Under the Sun.

4 Some examples include Showers, Imperial Gullies; Hodge, Triumph of the Expert; D'Avignon, "Primitive Techniques."

5 Ross, Ecology and Power, 4.

6 Beinart and McGregor, Social History; Beinart, Rise of Conservation.

7 Carruthers, The Kruger National Park; Carruthers, National Park Science.

8 Exceptions include Hecht, Being Nuclear; Peša, "Mining, Waste and Environmental Thought."

9 Exceptions include Ross, Ecology and Power; Kreike, Scorched Earth.

10 An overview of this literature is impossible, but good examples include
Bonneuil and Fressoz, The Shock of the Anthropocene; and Yusoff, A Billion Black Anthropocenes.

11 Hecht, "Interscalar Vehicles."

12 Yusoff, A Billion Black Anthropocenes.

13 Brownell, Gone to Ground.

14 MacKenzie, The Empire of Nature.

15 Beinart, Rise of Conservation.

16 Hughes, Whiteness in Zimbabwe; Pilossof, Unbearable Whiteness.

17 See Gewald, Spierenburg, and Wels, Nature Conservation; Swart, "Writing Animals into African History"; Mwatwara, "A History of State Veterinary Services."

18 Most notably, Carruthers, The Kruger National Park.

19 Harries, Work, Culture, and Identity.

20 Firenzi, "The Changing Functions of Traditional Dance."

21 Scott, Seeing like a State; Tischler, Light and Power; Isaacman and Isaacman, Dams, Displacement; van Beusekom, Negotiating Development.

22 Exceptions are: Esselborn, "Environment, Memory, and the Groundnut Scheme"; 
Hogendorn and Scott, "The East African Groundnut Scheme"; Wood, The Groundnut Affair.

23 Also Hodge, Triumph of the Expert.

24 Hodge, Triumph of the Expert.

25 Rizzo, "What Was Left."

26 Esselborn, "Environment, Memory, and the Groundnut Scheme," 86.
27 Scott, Seeing like a State.

28 For a similar argument, see Peša, "Crops and Copper."

29 See Peša, "Sawdust Pellets"; Branch and Martiniello, "Charcoal Power."

30 See also Twagira, "Africanizing the History of Technology."

31 Brownell, Gone to Ground, 186. 